ТЕОРІЯ І МЕТОДИКА ПІДГОТОВКИ

СПОРТСМЕНІВ

\title{
METHODOLOGICAL DIRECTIONS OF THE DEVELOPMENT OF A MODEL OF INDIVIDUALIZATION OF TRAINING OF SPORTSMEN SPECIALIZING IN SPEED POWER TYPE OF ATHLETICS
}

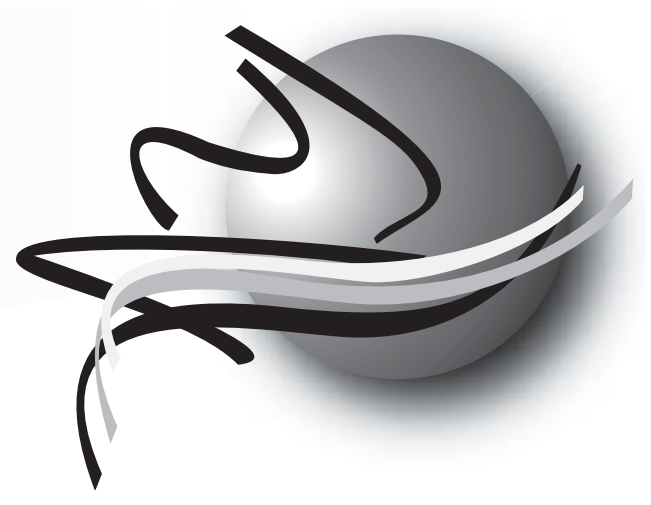

\author{
Vrublevskiy Evgeniy ${ }^{l, 2}$, Kozhedub Marina ${ }^{l}$, \\ Sevdalev Sergey ${ }^{l}$, Kowalski Pavel ${ }^{2}$ \\ ${ }^{1}$ Francisk Skorina Gomel State University, Belarus \\ ${ }^{2}$ University of Zielona Gora, Poland
}

DOI: 10.32540/2071-1476-2019-4-013

\section{Annotations}

Today, an increasing number of negative consequences are accumulating arising from the unreasonable compromises of the leveling concept in the training process. Due to these circumstances, it is more meaningful to recognize that, as the results of women move closer to the zone of sporting achievements, this approach is not only archaic, but also irrational, since it is in principle at odds with the unique specific features of the female body. All this can not but have a negative impact on the level of sporting achievements and on the health status of athletes in the range of the entire system of many years of sports training - from beginner to international sports master.

The purpose of the study is to develop and substantiate an innovative model of the individualization of training women in speed-strength types of athletics based on dimorphic features. The set of methods used to solve the tasks included: theoretical analysis and synthesis of data from the scientific and methodological literature; psychological and pedagogical testing, interview, pedagogical observation and experiment, modeling and forecasting, methods of statistical processing of the material obtained. Instrumental techniques were used in the work: photoelectronic timing, polydynamometry, seismic myotometry, video tape recorder, anthropometry.

The results of the study. The main directions were determined and the sequence of decision-making in the individualization of training of qualified athletes was established, which represented a system of logical prerequisites that mainly determined the organization of the real preparation process. On the basis of the latter, training organization models have been developed, tested in a series of pedagogical experiments on qualified female athletes specializing in speed-strength athletics (sprint, triple jump, hammer throwing). The models include streamlining the training load within the boundaries of the preparation stages and the components of their mesocycles, as well as rational ways of combining the latter into a single system, taking into account the specifics of the type of athletics, the training period, the qualification of the athlete and the inherent individuality.

Findings. The implementation of the developed models in the practice of training qualified athletes specializing in speed-strength types of athletics, showed their high productivity. These models, based on consideration of the morphological and functional features of the female athletes, biorhythmic patterns of its operation, synchronization of the training structure and the OMC phases, increased the efficiency of the training process and the effectiveness of competitive activity without increasing the volume and intensity of the applied loads, made the training process more manageable.

Keywords: individualization, athletics, athletes, training, ovarian-menstrual cycle, models. 


\section{Анотація}

Сьогодні накопичується все більша кількість негативних наслідків, що випливають 3 нерозумних компромісів зрівняльної концепції в тренувальному процесі. В силу цих обставин більш осмисленим стає визнання того положення, що, відповідно до зміни результатів жінок ближче до зони спортивних граничних досягнень, такий підхід вже не тільки архаїчний, але і нераціональний, оскільки він у принципі розходиться з унікальними специфічними особливостями жіночого організму. Все це не може не позначатися негативно і на рівні спортивних досягнень, і на стані здоров'я спортсменок в діапазоні всієї системи багаторічної спортивної підготовки, - від новачка до майстра спорту міжнародного класу.

Мета дослідження - розробити і обгрунтувати інноваційну модель індивідуалізації підготовки жінок у швидкісно-силових видах легкої атлетики на основі діморфічних особливостей. Сукупність методів, використовуваних для вирішення поставлених завдань, включала: теоретичний аналіз і узагальнення даних науково-методичної літератури; психологічне та педагогічне тестування, анкетування, педагогічне спостереження і експеримент, моделювання і прогнозування, методи статистичної обробки отриманого матеріалу. В роботі використовувалися інструментальні методики: фотоелектронний хронометраж, полідінамометрія, сейсмоміотонометрія, відеомагнітоскопія, антропометрія.

Результати дослідження. Були визначені основні напрямки і встановлена послідовність прийняття рішень при індивідуалізації підготовки кваліфікованих легкоатлеток, які представляли собою систему логічних передумов, переважно визначають організацію реального процесу підготовки. На основі останніх розроблені моделі організації підготовки, перевірені в серії педагогічних експериментів на кваліфікованих спортсменок, які спеціалізуються у швидкісно-силових видах легкої атлетики (біг на короткі дистанції, потрійний стрибок, метання молота). Моделі включають впорядкування тренувального навантаження в межах етапів підготовки і складових їх мезоциклов, а також раціональні способи об'єднання останніх в єдину систему, з урахуванням специфіки виду легкої атлетики, періоду підготовки, кваліфікації спортсменки і властивою їй індивідуальності.

Висновки. Реалізація розроблених моделей у практиці підготовки кваліфікованих спортсменок, які спеціалізуються у швидкісно-силових видах легкої атлетики, показала їх високу продуктивність. Ці моделі, засновані на обліку морфофункціональних особливостей організму спортсменок, біорітмологіческіх закономірностей його функціонування, синхронізації структури підготовки і фаз ОМЦ, підвищили ефективність тренувального процесу і результативність змагальної діяльності без збільшення обсягу та інтенсивності застосовуваних навантажень, зробили тренувальний процес більш керованим.

Ключові слова: індивідуалізація, легка атлетика, спортсменки, тренування, оваріально-менструальний цикл, моделі.

\section{Аннотация}

Сегодня накапливается все большее количество отрицательных последствий, вытекающих из неразумных компромиссов уравнительной концепции в тренировочном процессе. В силу этих обстоятельств более осмысленным становится признание того положения, что, по мере смещения результатов женщин ближе к зоне спортивных предельных достижений, такой подход уже не только архаичен, но и нерационален, так как он в принципе расходится с уникальными специфическими особенностями женского организма. Все это не может не сказываться отрицательно и на уровне спортивных достижений, и на состоянии здоровья спортсменок в диапазоне всей системы многолетней спортивной подготовки - от новичка до мастера спорта международного класса.

Цель исследования - разработать и обосновать инновационную модель индивидуализации подготовки женщин в скоростно-силовых видах легкой атлетики на основе диморфических особенностей. Совокупность методов, используемых для решения поставленных задач, включала: теоретический анализ и обобщение данных научно-методической литературы; психологическое и педагогическое тестирование, анкетирование, педагогическое наблюдение и эксперимент, моделирование и прогнозирование, методы статистической обработки полученного материала. В работе использовались инструментальные методики: фотоэлектронный хронометраж, полидинамометрия, сейсмомиотонометрия, видеомагнитоскопия, антропометрия.

Результаты исследования. Были определены основные направления и установлена последовательность принятия решений при индивидуализации подготовки квалифицированных легкоатлеток, которые представляли собой систему логических предпосылок, преимущественно определяющих организацию реального процесса подготовки. На основе последних разработаны модели организации подготовки, проверенные в серии педагогических экспериментов на квалифицированных спортсменках, специализирующихся в 
скоростно-силовых видах легкой атлетики (бег на короткие дистанции, тройной прыжок, метание молота). Модели включают упорядочение тренировочной нагрузки в границах этапов подготовки и составляющих их мезоциклов, а также рациональные способы объединения последних в единую систему, с учетом специфики вида легкой атлетики, периода подготовки, квалификации спортсменки и присущей ей индивидуальности.

Выводы. Реализация разработанных моделей в практике подготовки квалифицированных спортсменок, специализирующихся в скоростно-силовых видах легкой атлетики, показала их высокую продуктивность. Данные модели, основанные на учете морфофункциональных особенностей организма спортсменок, биоритмологических закономерностей его функционирования, синхронизации структуры подготовки и фаз ОМЦ, повысили эффективность тренировочного процесса и результативность соревновательной деятельности без увеличения объема и интенсивности применяемых нагрузок, сделали тренировочный процесс более управляемым.

Ключевые слова: индивидуализация, легкая атлетика, спортсменки, тренировка, овариальноменструальный цикл, модели.

Introduction. Immeasurably increased requirements for the level and reliability of highly skilled athletes, huge amounts of training and competitive loads and the growing struggle with the use of ethically and valeologically unacceptable ways of increasing the level of sports performance in recent years have led to the need to find new ways to solve these problems (Vrublevsky, 2016; Issurin, 2016; Prystupa, 2017). At the same time, from the methodological standpoint of modernity, there is an urgent need for fundamental research related to the complex individualization of training and competitive activities of high-class athletes, which allows them to constructively increase the results of their training.

It becomes obvious that in the construction and practical implementation of training programs for athletes should lie the prerogative of obtaining individually programmed motor actions and training effects, and not the desire to perform the unsubstantiated (mostly directed to the maximum) parameters of the specified loads, which is typical for today (Borzov, 2013; Vrublevskiy, 2008). And although the individual works and recommendations define some provisions and rules for the individualization of the training of athletes (Kostyuchenko, 2017; Vrublevskiy, 2018), they do not solve the problem as a whole.

Meanwhile, the holistic method- ology and technology of individualizing the training of sportswomen needs additions and further development, and the lack of common views on the individual approach in organizing the training process of women in speed-strength types of athletics makes this a pressing solution to this problem. Thus, the high theoretical and practical significance of solving the problem of individualizing the training of highly qualified female athletes, different approaches to its study, the multiplicity of aspects of the consideration determined the direction of the research undertaken.

Hypothesis. The model of individualizing the training of athletes specializing in speed-strength types of athletics, will be pedagogically expedient, contribute to the growth of sportsmanship, minimize negative consequences for their health, if the design of its content will be taken into account:

- dimorphic features of the body of athletes;

- specifics of individual competitive activity;

- orientation of the training process to the maximum development of their dominant individual traits;

- the current state of athletes due to fluctuations in their performance in various phases of the $\mathrm{OMC}$;

- correction of coaching influences in accordance with gender differences.

The purpose of the study is to develop and substantiate an innovative model of the individualization of women's training in speedstrength types of athletics based on dimorphic features.

Material and methods. The set of methods used to solve the tasks included: theoretical analysis and synthesis of data from the scientific and methodological literature; psychological and pedagogical testing, interview, pedagogical observation and experiment, modeling and forecasting, methods of statistical processing of the material obtained. Instrumental techniques used in the work: photoelectronic timing, polydynamometry, seismic myotometry, video tape recorder, anthropometry.

The study involved qualified athletes in speed-strength (sprint and hurdling, hammer throw, triple run jump) types of athletics.

The results of the study. The main points that should be followed when organizing training loads in the mesocycles of women's training were identified. In the most general form, these provisions are as follows:

1. In the speed-strength types of athletics, the main tasks of the annual training cycle are close in content and, in general, boil down to the development of speed, special endurance and strength, and the improvement of the technical skills of athletes. However, the specificity of the form (sprint and hurdling, jumping and throwing) makes certain differences both in the share of 


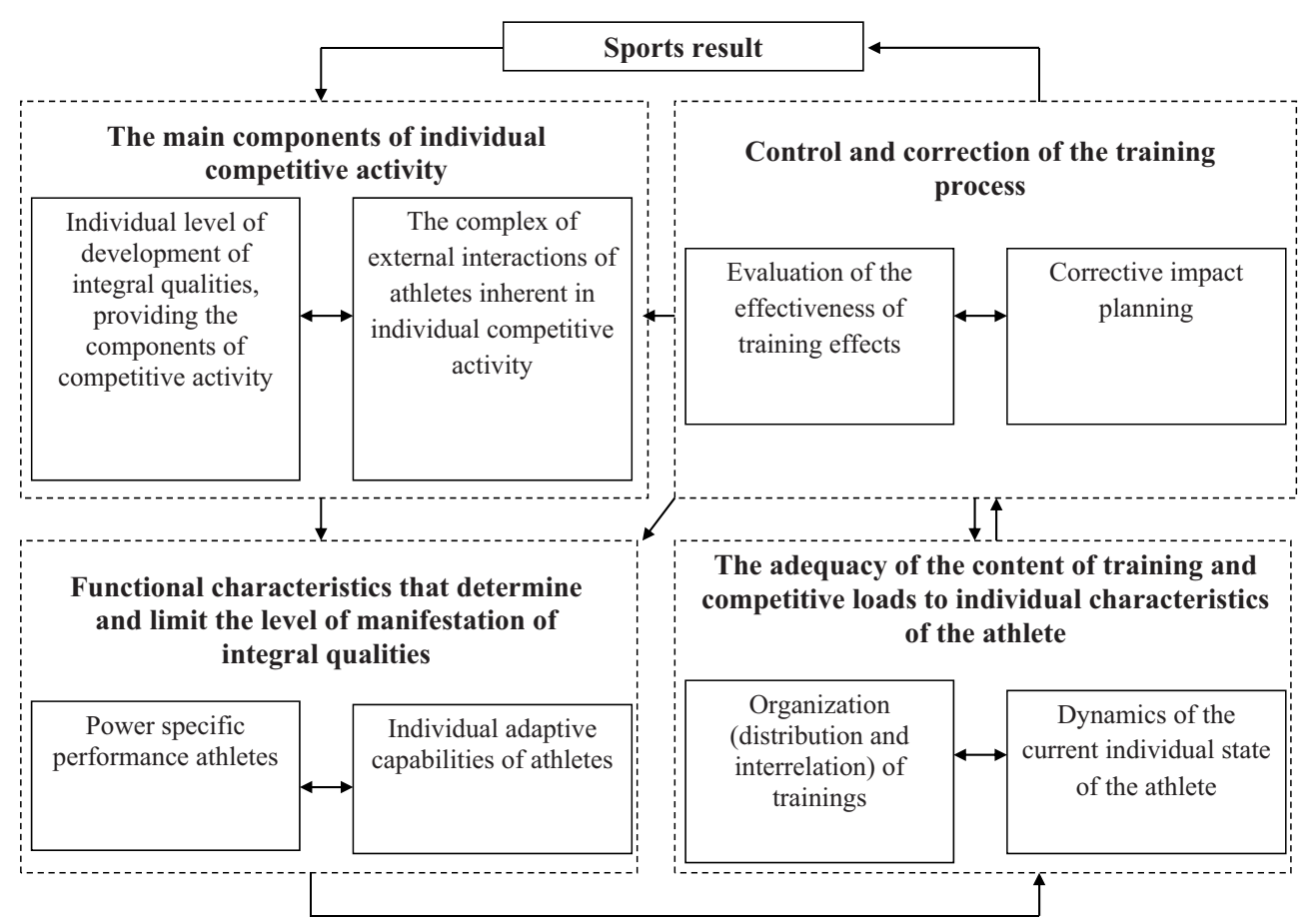

\section{Fig. 1 Sequence of decision-making in the individualization of the training} of highly qualified female athletes in speed-strength types

the volume of one or another trainee orientation, and in the choice of means for performing each type of load.

2. The structure of the training process for highly qualified female athletes (especially of the masculine type) is not significantly different from the training of men (with the exception of the total training loads on individual training means). At the same time, in the organization of the training process of athletes, it is necessary to take into account the specific biological features of the female body, considering the duration of an individual OMC as a mesocycle, and its individual phases as micro cycles of training.

3. The level of manifestation of the main motor abilities of female athletes, determining the result in the speed-strength types of athletics, varies throughout the OMC. In particular, the implementation of large amounts of exercise with the burden during the menstrual, ovulatory and premenstrual phases, and jumping exercises in the menstrual and premenstrual phases is undesirable, because can lead to violations of the reproductive system of female athletes.

4. Gender identity has a definite connection with the nature of the flow of menstrual function, affects the psychological attitude to the performance of training loads during a particular phase of the OMC, and also determines the characteristics of the dynamics of the manifestation of motor abilities during a specific cycle.

The decision-making sequence was established when individualizing the training of highly qualified female athletes in the speed-strength types of athletics (fig. 1), which is a system of logical prerequisites that predominantly determine the organization of the actual process of preparing a specific athlete.

On the basis of the above areas and the decision-making sequence for the individualization of training, training organization models have been developed that have been tested in a series of pedagogical experiments on qualified female athletes specializing in speed-strength types of athletics (sprint, triple jump, hammer throw).

When developing models, the fact that the absolute requirement that at this level of skill all athletes trained in a single model plan, without prejudice to their individual characteristics, is not the most effective, was taken into account. Therefore, the creation of these models was based on general principles that determine the most rational forms of training in a particular athletics discipline, and the practical role of the model was that it acted as a constructive basis for the individualization of the training process of a particular athlete.

The model of individualization of training reflected the interrelation of the most essential parameters of the content of the training process over time, as well as the general strategy of its construction, based on the cal- 


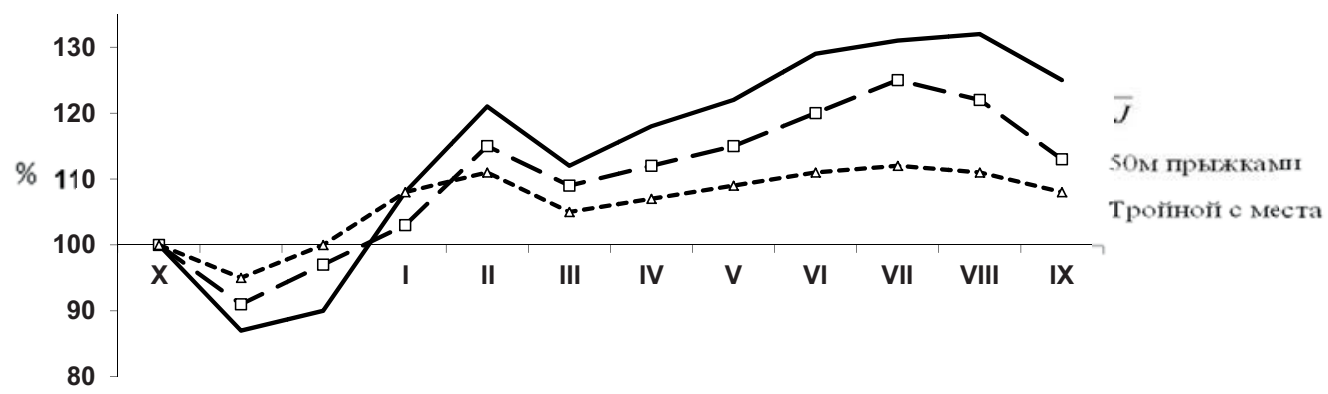

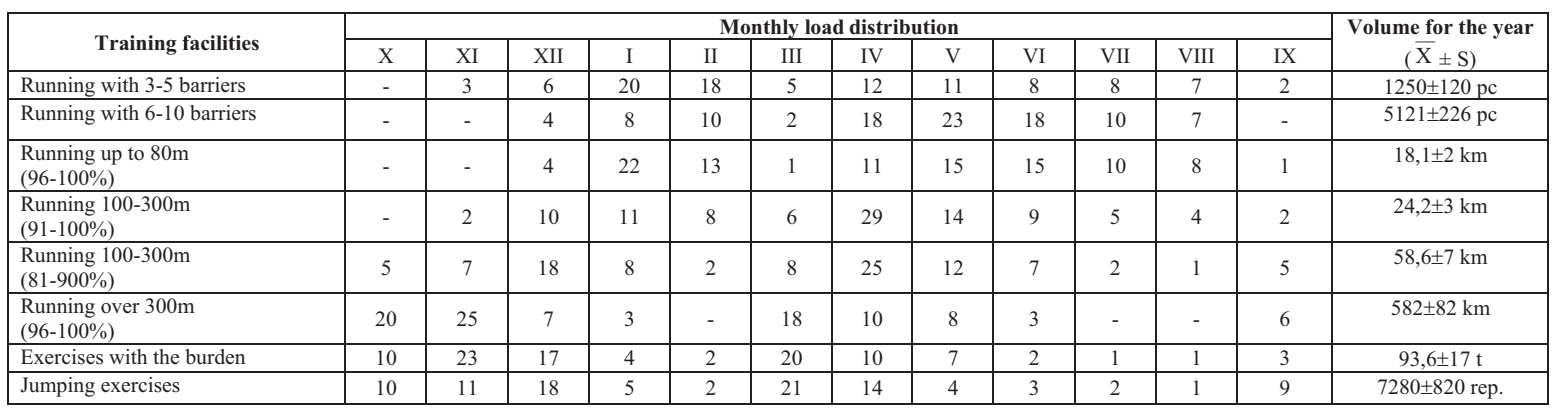

Fig.2 Model of individualization of the training of an athlete in the annual cycle of training (for example, running at $100 \mathrm{~m}$ with barriers): at the top - a model of the dynamics of explosive muscle strength and the results of jump tests Below - distribution of fixed assets of preparation as a percentage of annual volume (100\%)

endar of competitions and a number of other factors, which, first of all, include the peculiarities of changes in the individual level of athletes' special preparedness depending on the content, amount and organization of training load, as well as cyclical functions of the reproductive system of the body (fig. 2).

The effectiveness of the models was evaluated from the point of view of both improving the athletic skill of athletes, improving their well-being and psychological stability throughout the OMC, and reducing the possible negative impact of individual training effects on athletic reproductive disorders.

To do this, each pedagogical experiment, in which qualified athletes specializing in speed-strength athletics participated, was conducted in two stages. At first, during the year (from november to august), using the methodology for assessing the main muscle manifestations and jump tests, the relationship between the value of the specified training load and the athlete's condition was determined. Recorded performed training load on groups of fixed assets used in this type of athletics, and its individualized impact on the athlete's body. Testing was carried out twice, and at separate stages three times a month, without interfering with the course of training.

Studies have shown that the form of the relationship between the state of an individual athlete and the training load is ambiguous and extremely complex. Meanwhile, making decisions aimed at choosing the optimal variant of organizing a workout to achieve a given level of specific performance of a particular athlete requires knowledge of the characteristics of the dynamics of her particular state. It is the latter that serves as the central conceptual and substantive part of the concept of individualization of training, as well as the main factor determining the content, volume and distribution of training effects in the structural formations of the annual cycle and is the key to the scientific solution of the problem of individualization of training, as well as managing its progress.
At the end of the first stage of the experiment, together with the athlete's coach, the results were analyzed, and based on them, as well as based on the calendar of competitions and training tasks for the next year, a promising individual model of the dynamics of the athlete's condition and a system of coaching influences for its implementation were developed. At the same time, the training was planned with the expectation, first of all, of a very specific (and pre-planned) orientation in the individual dynamics of the level of special preparedness of a particular athlete and (in particular, relaxin), mobility in the joints increases and the elasticity of their ligamentous apparatus increases. Considering this, in the named phase it was expedient to work on the development of flexibility in an athlete. The training method here is preferable to the uniform and the game with an increase in the intervals of rest.

In the second micro cycle (postmenstrual phase), qualified athletes can perform a large amount and 


\section{Exemplary options for building an individualized mesocycle in the training process of female athletes, taking into account the biorhythmic of their body}

\begin{tabular}{|l|c|c|c|l|c|}
\hline \multirow{2}{*}{$\begin{array}{c}\text { Phase of the } \\
\text { biological cycle }\end{array}$} & \multicolumn{3}{|c|}{$\begin{array}{c}\text { The duration of the biological } \\
\text { cycle and its individual phases }\end{array}$} & \multirow{2}{*}{ The main focus of training sessions } & $\begin{array}{c}\% \text { total } \\
\text { monthly load }\end{array}$ \\
\cline { 2 - 5 } & 21 days & 28 days & 35 days & & $13-14$ \\
\hline $\begin{array}{l}\text { Premenstrual } \\
\text { and menstrual }\end{array}$ & $4-6$ & $4-7$ & $5-8$ & $\begin{array}{l}\text { General endurance, flexibil- } \\
\text { ity and mobility in joints }\end{array}$ & $36-37$ \\
\hline Postmenstrual & $5-6$ & $7-8$ & $10-11$ & $\begin{array}{l}\text { The development of special endur- } \\
\text { ance, speed-strength abilities }\end{array}$ & $7-8$ \\
\hline Ovulatory & $2-3$ & $2-3$ & $3-4$ & $\begin{array}{l}\text { The development of speed abili- } \\
\text { ties (in a small volume) }\end{array}$ & $40-42$ \\
\hline Postovulatory & $6-7$ & $8-9$ & $11-12$ & $\begin{array}{l}\text { The development of speed-power, } \\
\text { speed and coordination abilities }\end{array}$ & 4 \\
\hline
\end{tabular}

intensity of training load. Here it is advisable to plan training effects aimed at the development of speedpower abilities and special endurance. The increase in the latter is due to the increase in the rate of excitation of the central nervous system and the content of estrogen in the blood. Do not use exercises with a predominant load on the muscles of the lower extremities and the abdominals.

In the third microcycle (ovulation phase), according to the dominant principle, all kinds of activities become secondary (Dmitrieva, 2003; Pokholenchuk, 1987). That is why athletes, even with good fitness, in this phase mobilization of functional reserves decreases, coordination of movements is disturbed, and an increase in technical errors (Kostyuchenko, 2018; Filgina, 2017; Shakhlina, 2014) is likely. During this period, a small amount of speed work is possible.

In the fourth microcycle (postovulatory phase) athletes can perform the largest in amount and intensity of the load (40-42\% of the total for the month). It is determined that the improvement of speed abilities in running here is due to an increase in the length of the running steps. Productive work in this phase contributes to an increased level of hemoglobin in the blood.

In the fifth microcycle (premenstrual phase), due to the development of premenstrual syndrome, performance deteriorates, coordination of movements is disturbed, and the manifestation of strength and speed decreases. To a certain extent, this is due to a violation of watersalt metabolism, which is expressed in the swelling of the eyelids, arms, legs, anterior abdominal wall and lower back. Such conditions are accompanied by a significant increase in body weight (from $600 \mathrm{~g}$ to 2,5kg) (Dmitrieva, 2003; Roda, 2014; Vrublevskiy, 2017). During this period, athletes should not perform physical activities associated with the work of the abdominal muscles and pelvic floor, should be eliminated jumping elements, deep squats, especially with weights. Otherwise, the state of the reproductive organs may be disturbed. Performing strength exercises with great intensity should be limited to a minimum.

Such a construction of the training process, taking into account the biological characteristics of the female body, will ensure a higher overall performance and, without losing the training time of athletes, creates the prerequisites for the proper level of their special preparedness. At the same time, the monitoring of individual dynamics of athletic performance in various phases of the biological cycle and the focus of the training process, taking into account the biorhythmic of her body, largely optimize strategic approaches in preparation for the main competitions of the season. It should be borne in mind that the special performance of female athletes in various phases of the $\mathrm{OMC}$ at the initial stages of the annual cycle changes most significantly, the differences in the competition period are smoothed out, and the athletes can be trained with less consideration of the OMC phases (Roda, 2015; Samolenko, 2012).

The effectiveness of the training program implementation was provided by the feedback system, whose function was to regularly (2-3 times per month) test assess the current status of the athlete, compare her real characteristics with the model and correct, if necessary, the training program. At the same time, the training program acted as the main technological basis for making the target installation a reality.

Testing was conducted for each athlete in the same, the most favor- 
able (postmenstrual or postovulatory) phase, which allowed to avoid errors in the results associated with changes in the level of motor abilities during the OMC. The use of the ovulation test in female athletes participating in the experiments made it possible to indirectly assess the state of their reproductive system.

The results of pedagogical experiments showed the feasibility of an individual approach in the implementation of the training process of athletes specializing in various speed-strength types of athletics. The growth of athletic achievements of sportswomen was based on identifying and accented development of the leading and "pulling up" lagging motor qualities, on the preferential development of special speed-power and speed manifestations, taking into account the individual characteristics of athletes.

Discussion. Tracing the dynamics of views on the process of preparing highly qualified athletes and trying to identify the most important, central element, we certainly face the problem of individualization. The latter is based on the fact that the highest result in sports is a single and unique phenomenon, and preparation for it requires every time a search for new ways. Therefore, the transformation of the general laws of growth of sportsmanship through the prism of the individual characteristics of an athlete is an extremely difficult task, and the active search for sports training reserves, according to a large number of specialists (Vrublevskiy, 2008; Kostyuchenko, 2017; Mirzoev, 2005; Vrublevskiy, 2018), makes the individualization of the training process one of the top priority issues studied.

Summarizing the literary data, it should be noted that although the need for individualization of the sports training of women is recognized by all authors without exception, the amount of research in this area is extremely small. Usually, this problem was considered only along the way, along with an analysis of other issues of training athletes. At the same time, the materials of the conducted research and own views on the solution of the problem allowed us to present the methodology for implementing the principle of individualization in the training of qualified athletes.

There are two main points of view on the relationship between OMC and health. Some experts deny the dependence of efficiency on the phases of the OMC athletes (Issurin, 2016). Another group of scientists (Vrublevskiy, 2008; Kostyuchenko, 2017; Samolenko, 2012; Filgina, 2017; Shakhlina, 2014; Vrublevskiy, 2018) believes that a different concentration of pop hormones in the body throughout the OMC changes the functional state of the body systems and, therefore, cannot but affect the performance of athletes.

Specialists who adhere to the "individual approach" note that each of the categories of athletes with the characteristics of the OMC that are unique to it has its own characteristics of the development of motor capabilities throughout its length, and the similarity in dynamics was observed regardless of the level of qualification (Vrublevsky, 2016; Kostyuchenko, 2017; Roda, 2015; Samolenko, 2015; Kenney, 2012).

At the same time, in our study, factors of the complex individualization of the training of female athletes were revealed, both generalized for all speed-strength types of athletics and its individual disciplines. A technique has been developed for determining group and individual characteristics of competitive activity and fitness of female athletes, which allows finding the most effective way to solve motor tasks.

It is proved that the priority is the technology of building models for the individualization of the training process of athletes specializing in speed-strength types of athletics, providing for a different composition of training means in the annual cycle, adequate to the nature of competitive activity and the individual characteristics of the organism. New data were obtained that determined the methodological techniques for synchronization of the structure of preparation in the mesocycles and the individual duration of the athletes' ovarian-menstrual cycle. The latter was partially considered in a number of papers (Kostyuchenko, 2017; Roda, 2014; Vrublevskiy, 2017).

In general, pedagogical experiments showed the effectiveness of the developed individually-oriented model of building a workout in the annual cycle of athletes specializing in individual speed-strength types of athletics and the effectiveness of putting into practice the main areas of individualization of training of qualified athletes.

\section{Findings.}

1. The results of the study allowed to develop methodological areas of individualization of training, both generalized for all speedstrength types of athletics, and for the individual, the material on which the work was carried out. The individualization of the training of athletes specializing in the speedstrength types of athletics should be based on conceptual provisions that determine:

- individualization of integral and special physical preparedness on the basis of modeling their promising individual competitive activity;

- correction of the training loads of athletes in direction and volume due to the current state of health in various phases of the biorhythmic organism;

- differentiation of training and competitive effects in accordance with the gender characteristics of athletes.

The most important generalized factor is the model of competitive activity, based on the biological characteristics of the athlete, the development technology of which is focused on the planned result, emphasizing the athletes' strengths and, 
to a certain extent, pulling up the laggards. Another significant factor is the synchronization of the structure of sports training, especially its mesocycles and microcycles, with the phases of the OMC.

2. Developed models of individualization of athletes in the annual cycle, providing for the most optimal dynamics of the state of athletes, depending on the calendar of competitions, a different composition of training tools, adequate to the nature of its competitive activities and the main aspects of fitness. The models include streamlining the training load within the boundaries of the preparation stages and the components of their mesocycles, as well as rational ways of combining the latter into a single system, taking into account the specifics of the type of athletics, the training period, the qualification of the athlete and her inherent individuality. The mesocycles, at the same time, as the basic structural units of the training structure programmed by nature, are a kind of "building blocks" that constitute the stages and periods of training.

3. The implementation of the developed models in the practice of training highly qualified athletes specializing in speed-strength types of athletics, showed their high productivity. These models, based on consideration of the morphological and functional features of the female athletes, biorhythmic patterns of its operation, synchronization of the training structure and the $\mathrm{OMC}$ phases, increased the efficiency of the training process and the effectiveness of competitive activity without increasing the volume and intensity of the applied loads, made the training process more manageable. Moreover, these advantages, as evidenced by the results of the study, appear the more obvious, the higher the qualification of athletes. This was confirmed by the results of pedagogical experiments to test the effectiveness of the developed models for the individualization of the training of athletes specializing in speed-strength athletics.

Conflict of interest. The authors declare that there is no conflict of interest.

\section{References}

1. Borzov, V.F. (2013) Preparation of athlete-sprinter: strategy, planning, technology. Science in the Olympic sport. №4. 71-82 pp. (in Russian).

2. Vrublevskiy, E.P. (2016) Athletics: basic knowledge (questions and answers). M. Sport. 240 p. (in Russian).

3. Vrublevskiy, E.P., Gretz, I.A. (2008) Problems and Prospects of Contemporary Women's Sport: a monograph. Smolensk: Smolensk State. Acad. physical culture, sport and tourism. 145 p. (in Russian).

4. Vrublevskiy, E.P., Sevdalev, S.V., Narskin, G.I., Kozhedub, M.S. Technology of individualization training of qualified athletes: theoretical and methodological aspects: monograph. Gomel. F. Skoruna GSU. 2016. 223p. (in Russian).

5. Dmitrieva, K.V. (2003) Biorhythms in the life of a woman. SPb. Nevsky Avenue. 2003. 160p. (in Russian).

6. Issurin, V.B (2016) Training of athletes of the XXI century. Scientific basis and the construction of training. (Translation from English). M. Sport. 454 p. (in Russian).

7. Kostyuchenko, V.F., Vrublevskiy, E.P., Kozhedub, M.S. (2017) Methods of individualized training of athletes in the annual cycle, specializing in sprinting. Scientific notes of the University. P.F. Lesgaft. №10 (152). 115-121 pp. (in Russian).

8. Mirzoev, O.M, Maslakov, V.M., Vrublevskiy, E.P. (2005) Improvement of the individual structure of competitive and training activities of highly skilled athletes: method. Manual. M. RGUFK. 202 p. (in

\section{Литература}

1. Борзов, В.Ф. (2013) Подготовка легкоатлетаспринтера: стратегия, планирование, технологии. Наука в олимпийском спорте. № 4. С. 71-82.

2. Врублевский, Е.П. (2016) Легкая атлетика: основы знаний (в вопросах и ответах). М. Спорт. 240 с.

3. Врублевский, Е.П., Грец, И.А. (2008) Проблемы и перспективы современного женского спорта: монография. Смоленск: Смоленская гос. акад. физ. культуры, спорта и туризма. 145 с.

4. Врублевский, Е.П., Севдалев, С.В., Нарскин, Г.И., Кожедуб, М.С. Технология индивидуализации подготовки квалифицированных спортсменок: теоретико-методические аспекты: монография. Гомель. ГГУ им. Ф. Скорины. 2016. $223 \mathrm{c}$.

5. Дмитриева, К.В. (2003) Биоритмы в жизни женщины. СПб. Невский проспект. 2003.160 с.

6. Иссурин, В.Б. (2016) Подготовка спортсменов XXI века. Научные основы и построение тренировки. Пер. с англ. М. Спорт. 454 с.

7. Костюченко, В.Ф., Врублевский, Е.П., Кожедуб, М.С. (2017) Методика индивидуализированной подготовки спортсменок в годичном цикле, специализирующихся в спринтерском беге. Ученые записки университета им. П.Ф. Лесгафта. № 10 (152). С.115-121.

8. Мирзоев, О.М., Маслаков, В.М., Врублевский, Е.П. (2005) Совершенствование индивидуальной структуры соревновательной и тренировочной деятельности высококвалифицированных легкоатлетов: метод. пособие. М. РГУФК. 202 с. 
Russian).

9. Pokholenchuk, Y.T., Svechnikova, N.V. (1987) Modern Women's Sport. Kiev. Health, 1987. 191 p. (in Russian).

10. Roda, O.B (2015) Specifics of the forming of basic mesocycles of the training process of the athletes that are specializing in the middle distance running: diss. Candidate Sciences of Physical education and sports: 24.00.01. Luck. 21 p. (in Ukrainian).

11. Samolenko, T., Krivoruchenko, E. (2012) Features of building the training process of runners for middle distances, taking into account cyclic changes in the female body. Physical training and sport. №. 1 (7). 262-267. pp. (in Russian).

12. Semenov, V.G., Vrublevskiy, E.P. (2000) Patterns of adaptive variability in the strength of the muscles of female sprinters in the process of the development of sportsmanship. Theory and practice of physical culture. No. 9. 22-24 pp. (in Russian).

13. Semenov, V.G., Smolyanov V.A., Vrublevskiy E.P. Methods of mathematical statistics in research on physical culture and sport: a training manual. Smolensk. SGIFK. 1998. 71 p. (in Russian).

14. Theoretical and methodical foundations of the control of the physical sport: monograph (2017) / V.M. Kostyukevich, E.P. Vrublevskiy, T.V. Wozniak. Vinnitsa. Planer. 191 p. (in Ukrainian).

15. Filgina, E.V. (2017) Theoretical and methodological foundations of the gender construction of physical training for weightlifting: author. dis. Dr. Ped. sciences. Minsk. 59 p. (in Russian).

16. Shakhlina, L.Y.-G., Vovchanytsya, Y.L., Kalitka, S.V. (2014) Features of the application of an individual approach in the preparation of highly qualified athletes with iron deficiency conditions. Sports medicine. 2. 22-26 pp. (in Russian).

17. Kenney L.W., Wilmore J.H., Costill D.L. (2012) Physiology of sports and exercise. Champaign, IL: Human Kinetics. 621 p. (in English).

18. Kostyuchenko V.F., Skidan A.A., Vrublevskiy E.P. (2018) The individual differentiated training design of health-promoting shaping with mature age women. Pedagogics, Psychology, Medical-Biological Problems of Physical Training and Sports. 6. 295300 pp. (in English).

19. Martins P., Rosado A., Ferreira V., Biscaia R. (2017) Examining the validity of the athlete engagement questionnaire (AEQ) in a portuguese sport setting. Motriz. Journal of Physichal Education. 20. 1-7 pp. (in English).

20. Prystupa Y., Tyshchenko V. (2017) Peculiar properties and dynamics of physiological indicators in team handball. Journal of Physical Education and Sport. 17(1). 335-341 pp. (in English).

21. Roda O. (2014). The dynamics of special efficiency of sportsmen, who specialize in middle distance
9. Похоленчук, Ю.Т., Свечникова, Н.В. (1987) Современный женский спорт. Киев. Здоров'я, 1987. 191 c.

10. Рода, О.Б. (2015) Специфіка побудови базових мезоциклів тренувального процесу спортсменів, які спеціалізуються з бігу на середні дистанції: автореф. дис. ... канд. наук з фіз. виховання і спорту: 24.00.01. Луцьк. 21 с.

11. Самоленко, Т., Криворученко, Е. (2012) Ocобенности построения тренировочного процесса бегуний на средние дистанции с учетом циклических изменений женского организма. Фізичне виховання та спорт. № 1(7). С.262-267.

12. Семенов, В.Г., Врублевский, Е.П. (2000) Закономерности адаптационной изменчивости силы мышц женщин-спринтеров в процессе становления спортивного мастерства. Теория и практика физической культуры. № 9. С. 22-24.

13. Теоретико-методичні основи контролю у фізичному вихованні та спорті: монографія (2017) / за заг. ред. В.М. Костюкевича, С.П. Врублевський, Т.В. Вознюк. Вінниця. Планер. 191 с.

14. Фильгина, Е.В. (2017) Теоретические и методические основы гендерного построения физической подготовки тяжелоатлеток: автореф. дис. ... д-ра пед. наук. Минск. 59 с.

15. Шахлина, Л.Я.-Г., Вовчаныця, Ю.Л., Калитка, С.В. (2014) Особенности применения индивидуального подхода при подготовке спортсменок высокой квалификации с железодефицитными состояниями. Спортивная медицина. 2. С. 22 26.

16. Kenney L.W., Wilmore J.H., Costill D.L. (2012). Physiology of sports and exercise. Champaign, IL: Human Kinetics. 621.

17. Kostyuchenko V.F., Skidan A.A., Vrublevskiy E.P. (2018). The individual differentiated training design of health-promoting shaping with mature age women. Pedagogics, Psychology, MedicalBiological Problems of Physical Training and Sports. 6. 295-300.

18. Martins P., Rosado A., Ferreira V., Biscaia R. (2017) Examining the validity of the athlete engagement questionnaire (AEQ) in a portuguese sport setting. Motriz. Journal of Physichal Education. 20. 1-7.

19. Prystupa Y., Tyshchenko V. (2017) Peculiar properties and dynamics of physiological indicators in team handball. Journal of Physical Education and Sport. 17(1). 335-341.

20. Roda O. (2014). The dynamics of special efficiency of sportsmen, who specialize in middle distance running. Health Problems of Civilization. 8. 1. 1823.

21. Vrublevskiy E., Kozhedub M., Sevdalev S. (2017) Dynamics of development of physical qualities for omc in female athletes. Спортивный вестник 
running. Health Problems of Civilization. 8. 1. 1823 pp. (in English).

22. Vrublevskiy E., Kozhedub M., Sevdalev S. (2017) Dynamics of development of physical qualities for OMC in female athletes. Sports Bulletin of the Dnieper. 2. 44-49 pp. (in English).

23. Vrublevskiy E., Kozhedub M., Sevdalev S. (2018) Individualization of training process of runners at various distances depending on biorhythmics of their body. Sports Bulletin of the Dnieper. 3. 10-16 pp. (in English).

24. Vrublevskiy E., Kozhedub, M. (2018). The level of specific motor properties in the individual phases of the menstrual cycle among young sportswomen practicing sprints. Rocznik Lubuski. 44. 2a. 105115 pp. (in English).
Приднепровья. 2. 44-49.

22. Vrublevskiy E., Kozhedub M., Sevdalev S. (2018) Individualization of training process of runners at various distances depending on biorhythmics of their body. Спортивный вестник Приднепровья. 3. 10-16.

23. Vrublevskiy, E. Kozhedub, M. (2018). The level of specific motor properties in the individual phases of the menstrual cycle among young sportswomen practicing sprints. Rocznik Lubuski. 44. 2a. 105115.

\section{Врублевский Евгений}

Гомельский государственный университет имени Ф. Скорины

Зеленогурский университет (Польша)

г. Пинск, ул. Кирова, 17a/3, 225720, Республика Беларусь

e-mail: vru-evg@yandex.ru, тел.+375(29)3221139

\section{Севдалев Сергей}

Гомельский государственный университет имени Ф. Скорины

г. Гомель, ул. Рокоссовского, 48, 246014, Республика Беларусь

e-mail: sevdalev@mail.ru, тел.+375(29)6781809

\section{Кожедуб Марина}

Гомельский государственный университет имени Франциска Скорины

246000, г. Гомель, Гомель, ул. Жемчужная, д.26, кв. 22, 246013

e-mail: marina.888.k@yandex.ru тел.+375 296377931

Ковальский Павел

Зеленогурский университет (Польша)

ul. Licealna 9, 65-417 Zielona Góra, Польша

e-mail: sekretariat@kwf.uz.zgora.pl тел. +48683283000 